\title{
Impact of Varying Herbicide Contaminated Soil on Biomarkers of Achatina achatina
}

\author{
UBANI, CS; *NWEZE, EJ; NWACHUKWU, JN; ARAZU, AV \\ Biomonitoring and Pollution control Unit, Department of Biochemistry, University of Nigeria, Nsukka, Nigeria \\ *Corresponding Author Email: ekene.nweze@unn.edu.ng
}

\begin{abstract}
Soil microrganisms or faunas play vital roles in biogeochemical cycles which maintain the state of equilibrium of mineral elements in soil ecosystem as well as impacting on its texture and structure in otherward productivity. The impact of herbicides on biological population of soil samples spiked with various herbicides such as: dragon (paraquat) dichloride, Action 40 (Dimethoate), Vanish (Glyphosate). Buta force (Butachlor) and Amino force (2, 4-D amine 720G/L) were investigated. The soils were spiked with $10 \%$ of the herbicides, incubated for 4 weeks and the oxidative stress as well as the acetylcholinesterase activity of soil faunas used as biomonitors. There was a progressive increase of lipid peroxidation in achatina achatina with vanish having the highest level of malondialdehyde $(5.12 \mathrm{mg} . \mathrm{dl})$ and dragon herbicides with the lowest levels on the second week $(2.67 \mathrm{mg} / \mathrm{dl})$. The sample contaminated with amino force herbicide had the least impact on glutathione levels $(1.66 \mathrm{mg} / \mathrm{dl})$ while the dragon herbicide depleted more of the glutathione levels $(1.31 \mathrm{mg} / \mathrm{dl})$. The Achatina achatina incubated with the soil sample spiked with vanish registered the highest catalase activity $(6.2 \mathrm{lU} / \mathrm{L})$ while action 40 recorded $3.9 \mathrm{IU} / \mathrm{L}$ as the least activity. Acetylcholineesterase activity seen in Achatina achatina incubated with soil sample 4(vanish) was inhibited beyond all other samples with $0.169 \mathrm{IU} \mathrm{g}_{\text { protein }}{ }^{-1}$ as the least value with the exception of amino force that depreciated to $0.108 \mathrm{IU}$ g protein ${ }^{-1}$ on the third week. This study reveals how detrimental these herbicides can be to achatina achatina which counsels the farmers on their selectivity for agricultural purposes.
\end{abstract}

\section{DOI: $\underline{\text { https://dx.doi.org/10.4314/jasem.v24i7.18 }}$}

Copyright: Copyright $(\subset) 2020$ Ubani et al. This is an open access article distributed under the Creative Commons Attribution License (CCL), which permits unrestricted use, distribution, and reproduction in any medium, provided the original work is properly cited.

Dates: Received: 16 May 2020; Revised: 29 June 2020; Accepted: 07 July 2020

Keywords: oxidative stress, acetylcholinesterase, herbicides, biomarkers, activity.

Industrialization and population boom have led to the need for famers to improve on the quality of their products as well as the yield. This quest instigated the origin of agrochemicals (Omari, 2014). They are chemicals used by farmers to upgrade the quality of agricultural practices and quantity of agricultural yield and as a panacea to combating the population boom. They range from fertilizers, herbicides and pesticides (Zhang et al., 2018). The attention given to the economic benefits of these agrochemicals is at its apex and are by far greater when juxtaposed to their environmental effects. This have led to the misuse and abuse of agrochemicals. The fact that most farmers are not enlightened or are illiterates have also played a role in magnifying the misuse of these chemicals leading to these side effects (Marian-Morales et al., 2013). The environmental fate of these chemicals can be seen in soil, air and water, destabilizing the ecosystem. They can be volatilized, adsorbed by soil surfaces depending on the soils organic matter and clay content, photodecomposition could occur as well as microbial and chemical decomposition. (Murray, 1999). The microbial and chemical decomposition of herbicides in the soil is determined by the microbial composition and the physicochemical properties of the soil. The degradants of these agrochemicals can also leach away from the root area to the ground water. Soil micro and macroflora or fauna are pivotal to biogeochemical cycles. These cycles keeps the soil minerals in equilibrium and maintains the soil texture and structure. These activities of soil organisms is what regulates and determines the availability of soil nutrients and ensures ecosystem sustainability (Smith et al., 2015). The Soil macro and mega fauna are designated as ecosystem engineers (Coleman and Wall, 2014) because of their roles in promoting biopores (burrows) and soil aggregates. This in turn governs the soils water holding capacity and oxygenation (Domene, 2016). These macro faunas ranges from termites to earthworms, spiders and snails. A lot of current agronomical practices leave footprints on soil fauna communities. The interpretation of this footprint can be seen on key soil ecological processes such as nutrient or water cycles that crop production relies on. For this, the soil micro and macrofaunas are good bioindicators for soil quality impact assessments. This also indicates the necessity to monitor their state of health in other to protect their existence and continuity. These in turn maintains the equilibrium. Achatina achatina is an African giant snail and species of a very large, air-breathing land snail. A source of animal protein for West Africans and because of their 
tendency to multiply, they have been cultivated for economic purposes. They contribute to biogeochemical cycles by decomposing humus and distribution of organic matter within soil horizons. They ingest soil and soil debris from the surface that may have been polluted with different agrochemicals these pollutants may bioaccumulate in the tissues or cause detrimental effects to these organisms (Nicca et al., 2012; Eneji et al., 2016). This also makes them a good biomonitoring organisms for toxicity and impact assessments. Environmental biomonitoring involves investigating and quantifying biomarker responses in sensitive organisms. This can be used to monitor the deleterious effect of some pollutants (Lionetto et al., 2019). These biomarkers are preferable tool for assessment in place of chemical quantification because there environmental impact can be significantly interpreted and evaluated (Nwachukwu et al., 2018). These biomarkers range from exposure markers to morphological damage, stress, genotoxicity and reproductive impairment. The aim of this study is to evaluate the impact of the use of various agrochemicals on the biomarkers of stress (in this case the antioxidant system, lipid peroxidation product) and exposure (acetylcholine esterase) using Achatina achatina as a biomonitoring tool.

\section{MATERIALS AND METHODS}

The instruments and chemicals used for this study were of analytical grades

Sample Collection: Collection of Herbicides: The herbicides used were procured from Ogige main market Nsukka. Enugu State. Dragon herbicides (paraquat dichloride), Action 40 (Dimethoate), Vanish (Glyphosate), Buta force (Butachlor) and Amino force (2, 4-D amine $720 \mathrm{G} / \mathrm{L})$.

Collection of Snails: The snail used for this study were obtained from a snail farm located in obukpa, Nsukka, Enugu State and transported to the Teaching and Research Farm of the Department of Crop Science, faculty of Agriculture, University of Nigeria, Nsukka. Nsukka.

Location of Study: The experiment was conducted at the Teaching and Research Farm of the Department of Crop Science, faculty of Agriculture, University of Nigeria, Nsukka. Nsukka is located at latitude 060 $52^{\prime} \mathrm{N}$ and Longitude $07024^{\prime} \mathrm{E}$ and on altitude of $447.2 \mathrm{~m}$ above sea level. The study was carried out in May, 2019 and lasted for 4weeks.

Preparation of Herbicides and Application: Twenty millilitres $(20 \mathrm{ml})$ of each of the herbicides were mixed with one litre of distilled water and applied to the soil samples in the plastic pots. The entire mixture was mixed using a wooden stirrer and samples taken for analysis weekly. The different samples were prepared in triplicate and labelled as follows; Sample 1= soil sample mixed with just water (control); Sample $2=$ soil sample mixed with dragon herbicide (paraquat dichloride $24 \%$ active ingredient); Sample $3=$ soil sample mixed with action 40 herbicide (Dimethoate $40 \%$ active ingredient); Sample $4=$ soil sample mixed with vanish herbicide (Glyphosate $41 \%$ active ingredient); Sample 5= soil sample mixed with buta force herbicide (Butachlor 50\% active ingredient). Sample 6=soil sample mixed with Amino force herbicide (2, 4-D amine $720 \mathrm{G} / \mathrm{L}$ active ingredient).

Snail Incubation: The procured snails were incubated with the polluted soil samples for four weeks and harvested for analysis

Homogenate preparation: The snail samples were homogenized in a phosphate buffer $(0.1 \mathrm{M}$ potassium phosphate with $\mathrm{pH} 7.4$ ) and centrifuged for $10 \mathrm{~min}$ with a speed of 10,000 rpm. The supernatant was filtered and used for analysis or stored at $-80^{\circ} \mathrm{C}$ until when ready.

Estimation of lipid peroxidation levels (Malondialdehyde): This was estimated spectrophotometrically as described by wallin et al. (1993). A total of four test tubes containing 0.9 mil of distilled water, $0.5 \mathrm{ml}$ of $25 \%$ tricloroacetic acid and $0.5 \mathrm{ml}$ of $17 \%$ thiobarbituric acid (TBA) in $0.3 \%$ $\mathrm{NaOH}$ were set up and added $0.1 \mathrm{ml}$ of the sample. The mixture was incubated for $40 \mathrm{~min}$ at $95^{\circ} \mathrm{C}$ and cooled after incubation in which $0.1 \mathrm{ml}$ of $20 \%$ sodium dodecyl sulphate was added and absorbance read at $532 \mathrm{~nm}$ and 600nm against blank.

Determination of reduced glutathione (GSH): The reduced glutathione level was determined by the method of Raja et al. (2007). The homogenate sample (1 ml) was mixed with $4 \mathrm{ml}$ of $10 \%$ trichloroacetic acid and centrifuged for $10 \mathrm{~min}$ at $3000 \mathrm{rpm}$ to separate the protein content in the sample. The supernatant $(0.01 \mathrm{ml})$ was mixed with $2 \mathrm{ml}$ of phosphate buffer $(\mathrm{pH}$ $8.4), 0.5 \mathrm{ml} \mathrm{o} 5$, 5-dithio-bis (2-nitrobenzoic acid) (DTNB) and $0.4 \mathrm{ml}$ of distilled water. The absorbance was read at $412 \mathrm{~nm}$ within $15 \mathrm{~min}$ in a spectrophotometer.

Determination of catalase: This was determined by the method of Aebi (1984). The principle behind this method is pivoted on the rate of $\mathrm{H}_{2} \mathrm{O}_{2}$ decomposition by catalase. A total of $100 \mu 1$ of the homogenate test sample with equivalent volume of absolute alcohol were incubated in an ice bath for $30 \mathrm{~min}$ to release the 
active enzyme. They were cooled after incubation and triton $\mathrm{X}-100(10 \mu \mathrm{l})$ was added. $50 \mu \mathrm{l}$ is taking from the resultant mixture and added into a cuvette containing $200 \mu \mathrm{l}$ phosphate buffer and $250 \mu \mathrm{l}$ of $0.066 \mathrm{M} \mathrm{H} 2 \mathrm{O} 2$ in phosphate buffer. The absorbance was read at $240 \mathrm{~nm}$ for $30 \mathrm{~s}$ using a spectrophotometer and expressed in $\mu$ moles of hydrogen peroxide degraded per minute per $\mathrm{mg}$ of protein as unit.

Determination of Acetylcholinesterase: This was determined according to the colorimetric procedure of Ellman et al. (1961). The homogenate sample $(200 \mu 1)$ was mixed with $2.55 \mathrm{ml}$ of $0.1 \mathrm{M}$ phosphate buffer $(\mathrm{pH}$ 8.0), $50 \mu$ l ethopropazine and $100 \mu \mathrm{L}$ DTNB. They were allowed to sit in a water bath at $30^{\circ} \mathrm{C}$ for $5 \mathrm{~min}$ and $20 \mu \mathrm{l}$ acetylcholine iodide were added. The decrease in absorbance was measured at $412 \mathrm{~nm}$ using a spectrophotometer (UV-Vis).

\section{RESULTS AND DISCUSION}

There was a progressive increase in the peroxidation levels as the time of exposure to these different herbicides amplified. The herbicide vanish had the highest levels $(5.12 \mathrm{mg} / \mathrm{dl})$ of malondialdehyde as seen in Fig 1. Dragon herbicide and buta force also recorded increased levels of lipid peroxidation to be 4.69 and $4.84 \mathrm{mg} / \mathrm{dl}$ respectively when compared to the control that had $2.13 \mathrm{mg} / \mathrm{dl}$ on the fourth week. Dragon recorded the least lipid peroxidation levels on the second week $(2.67 \mathrm{mg} / \mathrm{dl})$ of exposure but increased progressively up until the fourth week of the experiment. The variations observed in this study was not significant when compared amongst the herbicides. The increase in the lipid peroxidation levels was a function of the length of exposure to the herbicides and the constituent of the herbicides. Malondialdehyde which is a product of lipid peroxidation accustomed as a biomonitoring tool for assessing stress and disease conditions (singh et al., 2014). It is the paramount product of peroxidation of poly unsaturated fatty acids (PUFA) especially the arachidonic acid an omega- 6 fatty acid. This fatty acid can be seen present within the cell membranes. The level of MDA in cells designates the level of lipid peroxidation and cellular tissue damage. The toxicity or cellular damage is usually associated with excess generation of reactive oxygen species (ROS) (Langaro et al., 2017). The MDA levels in all samples as observed showed that there was a progressive increase in MDA levels as the week progressed. The increase in the MDA levels could be that the generated reactive oxygen species (ROS) has submerged the antioxidant system leading to the attack on these fatty acids producing MDA and lipid peroxides and in turn cell death or apoptosis. Ujowundu et al., (2018) also observed an increase in lipid peroxidation with the use of herbicide, paraquat based herbicide. Bhardwaj et al., (2019) also recorded high levels of lipid peroxidation with glyphosate based herbicide. The amino force recorded generally a lower level of lipid peroxidation across the week.

There was a steep decline as the week progressed in the glutathione (GSH) levels as seen in Fig. 2 when compared to the control. The Achatina achatina samples exposed to dragon herbicides had the most depleted levels of glutathione of on the last week of the experiment $(1.31 \mathrm{mg} / \mathrm{dl})$ while the sample contaminated with amino force herbicide had more of its glutathione levels. These levels where still a huge decrease when compared to the control that recorded $2.92 \mathrm{mg} / \mathrm{dl}$ on the fourth week of the experiment. The samples also exposed to amino force herbicide had more glutathione levels $(1.66 \mathrm{mg} / \mathrm{dl})$ when compared to other herbicide exposed samples. Glutathione, known to be a tripeptide that exists in cells in a ratio of reduced glutathione (GSH) is to oxidized form (GSSG). The value of this ratio also determines the health status of cells. Healthy cells have the ration of GSH to GSSG of above 100 while in stress or disease conditions it falls to about 10 (Pizzorno, 2014). It has also been investigated as a non-enzymatic antioxidant that plays vital roles in metabolic function and detoxification by scavenging free radicals present in the cells. The accumulation of GSSG activates apoptotic pathways in a cell. The decrease seen in glutathione levels can be attributed to the fact that the Achatina achatina cells are detoxifying itself by scavenging free radicals and donating the hydrogen in the sulfhydrl group of the GSH and being oxidized to GSSG. This is as a result of the provocation posed by the herbicides, a prevailing oxidative stress caused by the generation of radicals. Glutathione levels could also have been depleted as a result of its role during glutathione-mediated biotransformation of these herbicides. These mediated biotransformation usually eliminates lipid loving toxicants as well as heavy metals which is also contained in these herbicides (Jiang, 2019). This decrease was also recorded by Ujowumdu et al., (2018) who treated Albino rats with paraquat dichlorde based herbicide. A reduction in glutathione levels was also observed when glyphosate based herbicides were exposed to wistar rats (Larsen et al., 2012). Contrary to these uncovering, a study using a herbicide Roundup Transorb, there was an increase in GSH levels of Prochilodus lineatus exposed to the $5 \mathrm{mg} / \mathrm{L}$ concentration of herbicide following a temporary decrease in liver GSH level after $24 \mathrm{~h}$ of exposure to Roundup concentrations (Modesto and Martinez 2010). A study investigated by de Melo Tarouco et al. (2017) noted that there were no changes in GSH levels of Laeonereis acuta. 


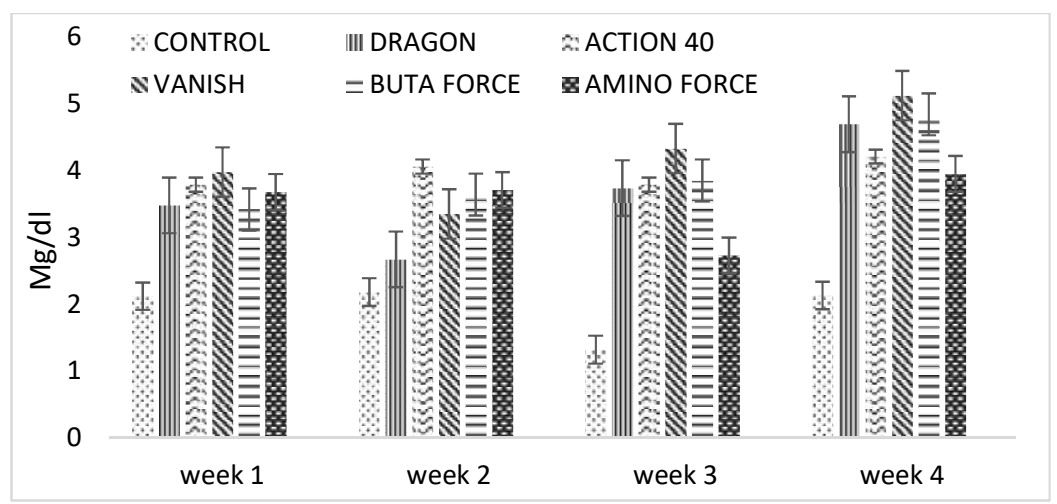

Fig. 1: Effect of herbicides on Malondialdehyde levels of Achatina achatina

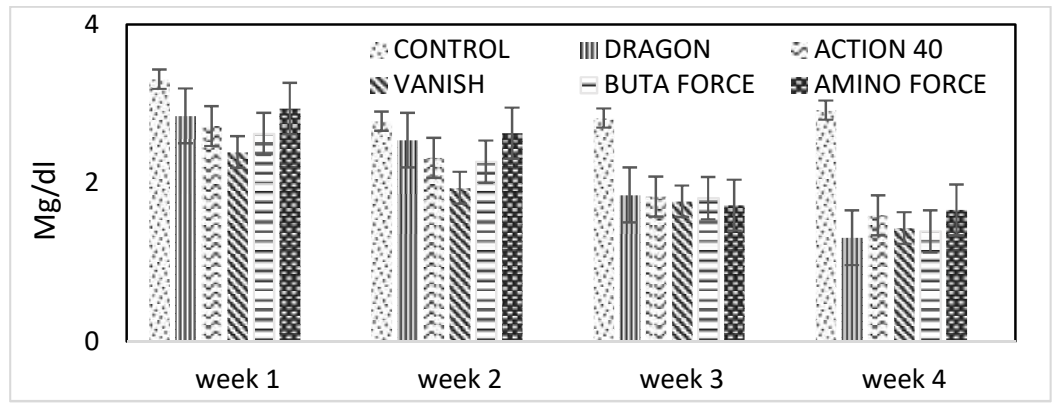

Fig. 2: Effect of herbicides on GSH levels of Achatina achatina

The catalase activity as seen in Fig. 3 increased as the time of exposure to the polluted soil increased. The Achatina achatina incubated with the soil sample spiked with vanish registered the highest catalase activity $(6.21 \mathrm{U} / \mathrm{L})$ on the fourth week when compared to both the control and other herbicides. Action 40 showed the lowest activity when compared to other herbicides with its activity being 3.9 IU/L. Catalase, an enzyme tetramer promotes the conversion of hydrogen peroxide to oxygen and water. Hydrogen peroxide a reactive oxygen species which can be damaging to cells during oxidative stress is monitored by this enzyme and therefore considered an antioxidant enzyme for this act (Liu and Kokare, 2017). The increase or decrease in activity of this enzyme is dependent on the level of the generated reactive oxygen species indicating when a cell is under stress. These stress conditions leads to the activation of apoptotic proteins in a cell and possibly cell death. The catalase activity as observed in this study had a steep increase with samples contaminated with dragon and vanish herbicides especially on the week three and four of the experiment. The Achatina achatina sample exposed to dragon herbicide polluted soil observed a steady increase all through the experiment but a decrease (4.12 IU/L) was recorded on the third week of the investigation. The activity increased finally to $4.79 \mathrm{IU} / \mathrm{L}$. The least activity $(3.91 \mathrm{IU} / \mathrm{L})$ recorded on the fourth week were observed by the samples exposed to action 40 during the investigation though higher when compared to the control. These herbicides contain components such as heavy metals which can instigate tissue burden via the over production of oxidants in the cells. The general increase in the catalase activity observed may be attributed to the increase in the generation of reactive oxygen species (ROS) in form of peroxides and hydrogen peroxides that overwhelms the antioxidant defence system of the Achatina achatina cells. This over generation of ROS is what causes the damages and further deterioration of Achatina achatina. This causes the catalase enzyme to mobilize themselves combating the excess build-up of ROS in other to cushion the effect. The perceived outcome seen in the sample exposed to action 40 on the third week could be that the antioxidant defence system tried to counter the impact of the generated ROS leading to the reduction of the spiked catalase activity. This increase in catalase activity was also in tandem with the studies done by Boudjema et al. (2014). Sağlam et al. (2014) who investigated the response of antioxidant defence system in fresh water fish (Oreochromis niloticus) exposed to metals in different hardness observed an increase in catalase activity. (Nwachukwu et al., 2018) also uncovered that there were increases in catalase activity of Achatina achatina obtained from mining sites with possible heavy metal contaminations. Bhangale and Mahajan, (2016) studied the impact of catalase activity in the 
digestive glands of the freshwater mussels, Lamellidens consobrinus spiked with heavy metals also noted an increase Similarly, there was an increase in catalase activity of Clarias gariepinus exposed to varying concentrations of glyphosate between week two and week eight of the analysis. (Ayanda 2018). Contrary to findings, Hong et al., 2018 who exposed a fresh water shrimp to herbicides noted decreases in catalase activity. The activity of this antioxidant enzyme may be increased or decreased in polluted environments depending on the chemical used (Sobjak et al. 2017). There are varriations about the results of its activity in the literatures which may be explained by potential antioxidant changes determined by either the habitat, species or the organ being investigated (Sobjak et al. 2017)

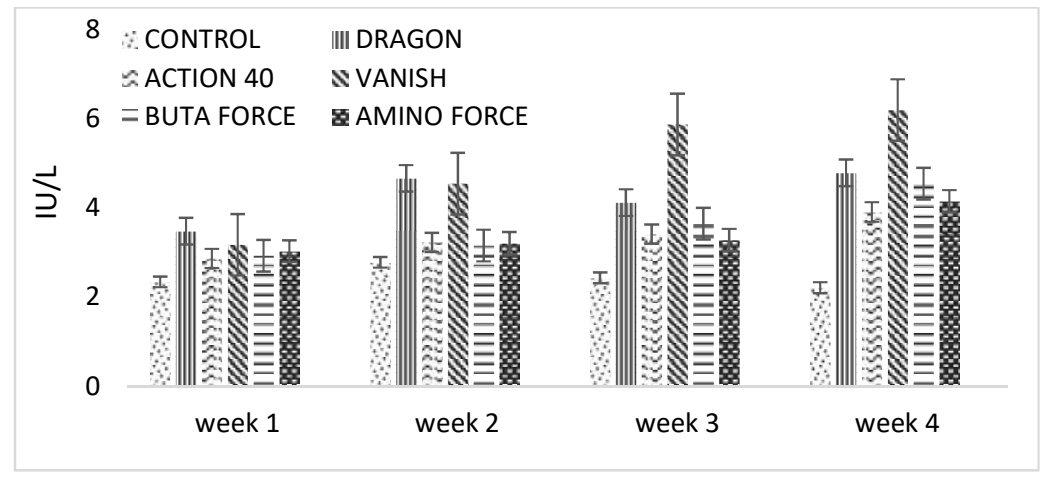

Fig. 3: Effect of herbicides on Catalase activity of Achatina achatina

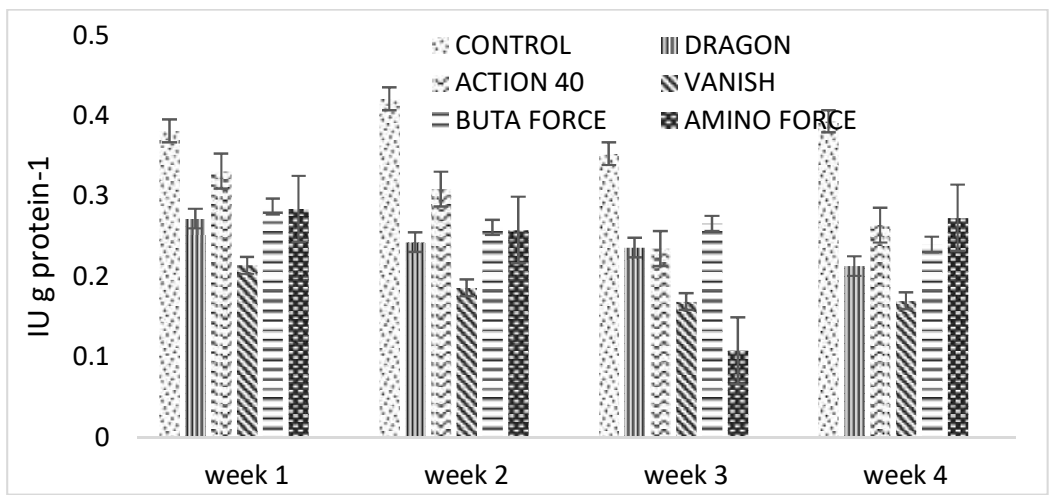

Fig. 4: Effect of herbicides on Acetylcholinesterase activity of Achatina achatina.

The manifested acetylcholineesterase activity seen in Achatina achatina incubated with soil sample 4(vanish) was inhibited (0.17 IU g protein $\left.{ }^{-1}\right)$ beyond all other samples with exception of the amino force that depreciated to $0.108 \mathrm{IU}$ g protein ${ }^{-1}$ on the third week and still climbed to $0.273 \mathrm{IU} g$ protein $^{-1}$ on the fourth week. Action 40 still retained a relatively high activity $\left(0.264 \mathrm{IU} \mathrm{g}_{\mathrm{g}}\right.$ protein $\left.^{-1}\right)$ when compared to the control at the end of the fourth week.

Acetylcholinesterases are neurotransmitter hydrolysers. They are hydrolytic enzymes which hydrolyses the neurotransmitter acetylcholine in to choline and ester. This transmitter is predominant at the neuromuscular junctions and brain synapses of Achatina achatina. Acetylcholinesterase is a potent regulator of the impact of this neurotransmitter. In a condition where this enzyme is subdued, it can cause the build-up of acetylcholine in the neuromuscular joints which over stimulates them and eventually becomes detrimental to the organism (Benfeito, 2014). This overstimulation can pilot the depletion of the cellular ATP thereby inflating the over production of ROS which in turn damages the tissues. This work noted the variations in the activity of acetylcholinesterase of Achatina achatina. As seen in this study, there was a general decrease in the activity of the enzyme as the time of exposure increased when compared to the control. This decrease can be attributed to metabolites that may be toxic to the neurotransmitter hydrolyser or a constituent heavy metal present in the herbicides. Heavy metals can interfere with the structure of this enzyme and their production as well. This structure and stability also determines their functionality (Colovic, 2013). The decrease in activity expressed in the samples exposed 
to soil contaminated with amino force (0.108 IU $\mathrm{g} /$ protein) and a sudden increase in activity to $0.273 \mathrm{IU}$ $\mathrm{g} /$ protein on the third week could be that there was a metabolite of the herbicide that was toxic to acetylcholinesterase which those achatina achatina samples was able to detoxify by the following week. This ability to detoxify may be attributed to the little improvement in motion observed by those samples. This decrease in acetylcholinesterase activity was also observed by Pala, (2019) whose results stipulated that the acetylcholinesterase activity in G. pulex was inhibited by 23 to $53 \%$ when exposed to a glyphosate based herbicides- round up. Modesto and Martinez (2010) findings were also in agreement with the reduction observed.

Conclusion: This study demonstrates that all the herbicide samples used induced oxidative stress and reduces the functionality of acetylcholinesterase and thus should be handle with care. It also counsels us on how damaging and detrimental the exposure to herbicides can be to Achatina achatina. This in otherward guides these farmers on selectivity in other to main the equilibria level of biogeochemical cycles that indirectly conserves the soils productivity

\section{REFERENCES}

Aebi, H (1984). Catalase. Methods in Enzymology 105:121-126.

Ayanda, OI (2018) Toxicity of sublethal concentrations of glyphosate and paraquat herbicide in the African catfish (Clarias gariepinus). Int. J. Agric. Biol., 6 (20):1359-1364

Benfeito, S; Tiago ST; Garrido, J; Andrade, PB; Sottomayor, MJ; Borges, F; Garrido EM (2014). Effects of Chlorophenoxy Herbicides and Their Main Transformation Products on DNA Damage and Acetylcholinesterase Activity. Biomed. Res. Int., 2014: 10

Bhangale, BS; Mahajan, PR (2016). Catalase activity in the digestive glands of the freshwater mussels, Lamellidens consobrinus after heavy metal stress. Int. J. Recent Sci Res., 7: 8863-8866.

Boudjema, K; Kourdali, S; Bounakous, N; Meknachi, A; Badis, A (2014). Catalase Activity in Brown Mussels (Perna perna) under Acute Cadmium, Lead, and Copper Exposure and Depuration Tests. J. of Mar. Biol., 2014: 9

Čolović, MB; Krstić, DZ; Lazarević-Pašti, TD; Bondžić, AM; Vasić, VM (2013). Acetylcholinesterase Inhibitors: Pharmacology and
Toxicology, Curr. Neuropharmacol. 11(3): 315335.

De Melo TF; De Godoi, FGA; Velasques, RR; Da Silveira Guerreiro, A, Geihs, MA; Da Rosa, C. E. (2017) Effects of the herbicide Roundup on the polychaeta Laeonereis acuta: cholinesterases and oxidative stress. Ecotoxicol. Environ. Saf, 135:259-266.

Domene, X (2016). A Critical Analysis of Meso- and Macrofauna Effects Following Biochar Supplementation. In: Komang Ralebitso, T. and Orr C, (ed). Biochar Application, Pp 268-292.

Ellman, GL; K.D. Courtney, V. Andres Jr. and R.M. Featherstone, (1961). A new and rapid colorimetric determination of acetylcholinesterase activity. Biochemical Pharmacology, 7: 88-95.

Eneji, I.S; Wuana, RA; Akpan, UJ (2016). Trace Metals Levels in African Giant Land Snails (Achatina achatina) from Selected Local Government Areas in Akwa Ibom State, Nigeria. Open Access Library Journal, 3: e2244. http://dx.doi.org/10.4236/oalib.1102244

Hong, Y; Yang, X.; Huang, Y; Yan, G; Cheng, Y (2018) Assessment of the oxidative and genotoxic effects of the glyphosate-based herbicide roundup on the freshwater shrimp, Macrobrachium nipponensis. Chemosphere, 210:896-906.

Jiang, x; Du, B; Zheng, J. (2019) Glutathionemediated biotransformation in the liver modulates nanoparticle transport. Nat. Nanotechnol., 14: 874882

Langaro, A C; Agostinetto, D; Ruchel, Q; Garcia, JR; Perboni, LT (2017). Oxidative stress caused by the use of preemergent herbicides in rice crops. Revista Ciência Agronômica 48(2): 358-364

Larsen, K; Najle R; Lifschitz, A; Virkel, G (2012). Effects of sub-lethal exposure of rats to the herbicide Glyphosate in drinking water: Glutathione Transferase enzyme acticities, level of reduced glutathione and lipif peroxidation in liver, kidneys and small intestine. Environ. Toxicol. Pharmacol., 34(3):811-818

Liu, X; Kokare, C.(2017). Microbial enzymes of use in industry. In: Goutam Brahmachari (ed). Biotechnology Microbial Enzymes, Academic Presss, USA. Pp: 267-298 
Marian-Morales, MA; Ventura - Camargo, BV; Hoshina, MM (2013) Toxicity of herbicides: impact on aquatic and soil biota and human health. In: Price, A. and Kelton, (ed). Herbicides-Current Research and Case Studies in use Doi: $10.5772 / 55851$

Modesto, KA; Martinez, CBR (2010). Effects of Roundup Transorb on fish: Hematology, antioxidant defenses and acetylcholinesterase activity. Chemosphere, 81: 781-787

Murray, TR; (1999). Turfgrass Herbicide Mode of Action and Environment Fate. Univ. of Georgia. College of Ag and Environ. Sci. Accessed 29 April 2015. https://pdfs.semanticscholar.org/e8ed/42544ba4b4 d328e34346a4351ad63d7ead39.pdf

Nica, DV; Bura, M; Gergen, I; Harmanescu, M; Bordean, D.M. (2012) Bioaccumulative and Conchological As- sessment of Heavy Metal Transfer in a Soil-Plant-Snail Food Chain. Chem. Cent. J. 6: 55-60.

Nwachukwu, JN; Ubani, CS; Osuji, CA (2018). Biomarkers in Achatina achatina as ecological risk assessment models of mining activities. Res $J$ of Env Toxi, 12: 63-72.

Omari, S. (2014) Assessing Farmers' knowledge of effects of agrochemical use on human health and the environment: a case study of Akuapem South Municipality, Ghana," Int. J. Appl. Sciences Eng. Res., 3(2): 402-410

Smith P; Cotrufo, MF; Rumpel, C; Paustian, K; Kuikman, PJ; Elliott, JA; McDowell, R; Griffiths, RI; Asakawa, S; Bustamante, M; House, JI; Sobocká, J; Harper, R; Pan, G; West, PC; Gerber, JS; Clark, JM; Adhya, T; Scholes RJ; Scholes MC (2015). Biogeochemical cycles and biodiversity as key drivers of ecosystem services provided by soils. SOIL, 1(2), 665-685.

Pala, A; (2019).The effect of a glyphosate-based herbicide on acetylcholinesterase (AChE) activity, oxidative stress, and antioxidant status in freshwater amphipod: Gammarus pulex (Crustacean). Environ. Sci. Pollut. Res., 26:36869-36877(2019)
Raja, S; Ahmed, K; Kumar, V; Mukherjee, K; Bandyopadhyay A (2007) Antioxidant effect of Cystisus scopararius against carbon tetrachloride treated liver injury in rats. $J$ Ehnopharm 109: 4147.

Sağlam, D G; Atli, Z; Dogan, E; Baysoy, C; Gurler, AE; M. Canli, (2014). Response of the antioxidant system of freshwater fish (Oreochromis niloticus) exposed to metals $(\mathrm{Cd}, \mathrm{Cu})$ in differing hardness. TURK J FISH AQUAT SC, 14: 43-52. 28.

Singh, Z; Karthigesu, IP; Singh, P; Kaur, R (2014). Use of malondialdehyde as a biomarker for assessing oxidative stress in different disease pathologies: A review. Iranian Journal of Public Health, 43(3): 7-16

Sobjak, T. M; Romão, S; Nascimento, CZ; Santos, AFP; Vogel, L; Guimarães, ATB (2017) Assessment of the oxidative and neurotoxic effects of glyphosate pesticide on the larvae of Rhamdia quelen fish. Chemosphere 182:267-275. 5

Vasilis, D (2019): Common biomarkers for the assessment of marine pollution. Availablefrom http://www.coastalwiki.org/wiki/C ommon biomarkers for the assessment of mari ne pollution [accessed on 1-03-2020]

Wallin, B; Rosengren, B; Shertze, RHG; Cameyo, G (1993) Lipoprotein oxidation and measurement of TBARS formation in a single microlitrepeate; its use for evaluation of antioxidants. Annual Rev Med 208:10-15.

Zhang L; Yan, C; Guo, Q; Zhang, J; Ruiz-Menjivar, J. (2018). The impact of agricultural chemical inputs on environment: global evidence from informetrics analysis and visualization. Int. J. Low-Carbon Tech., 13(4): 38-352 